\title{
Feeding of the Sparid Fish Sarpa salpa in a Seagrass Ecosystem: Diet and Carbon Flux
}

\author{
S. Havelange, G. Lepoint, P. Dauby \& J.-M. Bouquegneau \\ Ocáanologie, B6, Université de Liège, B-4000 Sart Tilman, Belgium.
}

With 3 figures and 2 tables

Key words: Sarpa salpa, Posidonia oceanica, feeding ecology, stable carbon isotopes.

\begin{abstract}
In Revellata Bay (Gulf of Calvi, Corsica, France), the sparid fish Sarpa salpa L. is the main macro-consumer of Posidonia oceanica (L.) DeLILE leaf. Stomach contents were analysed and ${ }^{13} \mathrm{C} /{ }^{12} \mathrm{C}$ isotopic ratios were measured in fish muscle and potential food sources (algae, $P$. oceanica leaf and its epiphytes) to determine their relative contribution to the fish diet. $S$. salpa has an age-related mixed diet: juveniles are plankton feeders, young, sub-adults and adults are herbivorous, and, the older the individuals. the higher the relative contribution of $P$. oceanica to the diet. Our results and former studies of carbon stocks and fluxes in the $P$. oceanica bed of Revellata Bay have enabled an estimation of the general impact of $S$. salpa grazing on infralittoral communities: the studied species consumes $24 \mathrm{~g}$ $C \cdot \mathrm{m}^{-2} \cdot \mathrm{a}^{-1}$ from $P$. oceanica leaf, 4.8 from epiphytes and 13 from epilithic algae. The fish net production and biomass turnover in that zone have been estimated to be $1.2 \mathrm{~g} \mathrm{C} \cdot \mathrm{m}^{-2} \cdot \mathrm{a}^{-1}$ and $1.5 \mathrm{a}^{-1}$, respectively.
\end{abstract}

\section{Problem}

The meadows of the seagrass Posidonia oceanica (L.) Dellue cover more than $2 \cdot 10^{4} \mathrm{~km}^{2}$ in the Mediterranean Sea (Pergent, 1993) and thus are considered as a key component in the ecology of its coastal zone. The ecology of this temperate seagrass species had been well studied (e.g., Kerneis 1960; Giraud, 1979; Bay, 1984; Libes, 1985; Frankignoulle \& Bouquegneau, 1987; Meinesz et al., 1988; Velimirov \& Walenta-Simon, 1992, 1993; Pergent et al., 1994; Romero et al., 1994), but the role of macro-consumers in the recycling of $P$. oceanica production remains insufficiently investigated (MAzzella et al., 1992). Potential consumers include the sparid fish Sarpa salpa L. (Velimirov, 1984; Verlaque, 1990), the echinid Paracentrotus lividus Lam. (OtT \& Maurer, 1977; Traer, 1980; Nedelec \& Verlaque, 1984; Zupo \& Fresi, 1984) and the isopod Idotea baltica Pall. (LORENTI \& FRESI, 1983). The relative importance of these three macro-consumers displays a great variation from one meadow to another along the Mediterranean coast: e.g., in Lacco Ameno meadow, Ischia, $P$. lividus is by far the main macroconsumer (TraER, 1980), while in the Spanish Mediterranean, S. salpa contributes about $75 \%$ of total herbivory consumption (CEBRIEN et al., 1996). However, herbivore appears to be a minor factor in the control of $P$. oceanica since it only 
accounts for about $2 \%$ of its leaf production (CEBRIAN et al., 1996). In the Gulf of Calvi (Corsica), the $P$. oceanica meadow covers $10 \mathrm{~km}^{2}(\mathrm{BAY}, 1984)$ and its main leaf macro-consumer is $S$. salpa, grazing about $15 \%$ of the net primary production (Bouquegneau et al., 1994).

WhITEHEAD et al. (1986) describe $S$. salpa as omnivorous, young fish mainly being carnivorous (crustaceans), while adult fishes are almost exclusively herbivorous: the species displays a highly adapted dentition: in both jaws incisors are uniserial. upper ones notched, lower ones depressed on their outer face and ending in a single triangular point; all incisors have well visible roots inside the mouth.

However, the main food sources for the various age-classes of $S$. salpa remains debatable. According to Velimirov (1984), S. salpa grazes mainly on the seagrass, while VerLaQue (1990) claimed that $S$. salpa grazes mainly on epilithic algae; neither author takes the epiphytic covering of $P$. oceanica into account as a potential food source.

The aim of this work is to detail the trophic relationships between the sparid fish $S$ s salpa and the three following potential food sources: (1) P. oceanica leaves, (2) epiphytic community of $P$. oceanica (both flora and fauna) and (3) adjacent epilithic algae. Our results and data from Velimirov (1984), Bouquegniau el al. (1994) and LEPOINT et al. (in press) have been integrated into a box-flux model of the carbon transfer towards $S$. salpa in Revellata Bay.

\section{Material and Methods}

Our investigation was conducted near the marine research station STARESO (Corsica, 42 35' N $843^{\prime}$ E) between 5 and $15 \mathrm{~m}$ depth (Fig. 1). At $10 \mathrm{~m}$, the $P$. oceanica shoot density ranges from 349 shoots $\cdot \mathrm{m}^{2}$ to 467 shoots $\cdot \mathrm{m}^{2}$ depending on the location and time of year (SoULLARI) ("t al., 1994).

Fig. I. Study site; dark stippling = fish catch area. 
The meadow is surrounded on its upper limit (from the surface to $7 \mathrm{~m}$ depth) by rocks covered by a rich macroalgae biocenosis (epilithic algae).

We used qualitative stomach content analyses and comparative measurements of the isotopic ${ }^{13} \mathrm{C} /{ }^{12} \mathrm{C}$ ratios of both the fish muscle tissue and the three above mentioned potential food sources of the fish.

Posidonia oceanica leaf distal parts (the uppermost $15 \mathrm{~cm}$ ) and epilithic algae (Halopteris sp. and Dictrota sp.) were collected by SCUBA diving at depths of 10 and $5 \mathrm{~m}$, respectively. Epiphytes were completely removed with a blade scraper, according to DAUBY \& PouliceK (1995). Seventy-five fish were caught by net or speared. Each captured fish was measured (total and standard length: TL and $\mathrm{SL}$ ) in $\mathrm{cm}$ and dissected; lateral muscle and stomach contents were sampled. When possible, the total digestive tract length was measured $(\mathrm{gL})$ in $\mathrm{cm}$. Fish were sorted into five length classes according to Faggianelli \& COOK (1981).

The relative length of the gut calculated as the ratio of gut to body length $(\mathrm{RLG}=\mathrm{gL} / \mathrm{SL})$ correlates in most cases with the fish diet. RLG is generally lower than 0.1 for carnivorous fish, higher than 3 for herbivores, and intermediate for omnivores (SUyehiRo, 1942; KLUMPP \& NiCHOLS, 1983). The RLG of $30 \mathrm{~S}$. salpa specimens was calculated and averaged in the length classes.

In order to estimate the relative contributions of epilithic algae, $P$. oceanica leaves and epiphytes to the fish diet, both food sources and the fish muscle tissue $\delta^{13} \mathrm{C}$ were measured. Samples were slightly acidified to remove inorganic carbonates (except for the fish muscle), rinsed and oven-dried at $50^{\circ} \mathrm{C}$ for several days. They were then ground into fine powder and combusted in the presence of copper oxide wire at $500 \mathrm{C}$ in vacuum sealed Pyrex tubes (SoFer, 1980). The generated $\mathrm{CO}_{2}$ was purified cryogenically and analysed on an Optima 540 (Micromass) IR-MS. All values are reported relative to the international PDB as

$$
\delta^{13} \mathrm{C}=\left[\left(\mathbf{R}_{\text {sample }}-\mathbf{R}_{\text {standard }}\right) / \mathbf{R}_{\text {standarcl }}\right] \times 1000,
$$

where $\mathrm{R}$ is the ${ }^{13} \mathrm{C} /{ }^{12} \mathrm{C}$ ratio. Routine measurements are precise to within 0.1 .

DE NiRo \& EPSTEIN (1978) and Fry et al. (1987) have shown that the $\delta^{13} \mathrm{C}$ of a consumer is slightly (about 1) enriched in ${ }^{13} \mathrm{C}$ compared to the consumer's food, and this should be subtracted from all muscle measurements in order to estimate the $\delta^{13} \mathrm{C}$ of the food source. Thus, the relative contribution of the three potential carbon sources $\left(\mathrm{rc}_{\text {algae }}, \mathrm{rc}_{\text {leaves }}\right.$ and $\left.\mathrm{rc}_{\text {epiphytes }}\right)$ to $S$. salpa diet has been calculated from the following three equations (modified from DaUBY, 1989):

$$
\begin{gathered}
\mathrm{rc}_{\text {algac }}+\mathrm{rc}_{\text {leaves }}+\mathrm{rc}_{\text {epiphytes }}=100 \% \\
\mathrm{rc}_{\text {epiphyles }} / \mathrm{rc}_{\text {leaves }}= \\
\delta^{13} \mathrm{C}_{\text {foud }}=\left(\mathrm{rc}_{\text {algat }} \times \delta^{13} \mathrm{C}_{\text {algac }}\right)+\left(\mathrm{rc}_{\text {leaves }} \times \delta^{13} \mathrm{C}_{\text {leaves }}\right)+\left(\mathrm{rc}_{\text {epiphytes }} \times \delta^{13} \mathrm{C}_{\text {epiphytes }}\right)
\end{gathered}
$$

where 'biomass' is the amount of matter on leaf tips, ' $\mathrm{Cc}$ ' is the organic carbon contents (in \% of dry weight biomass), 'Aefr is the assimilation efficiencies of food carbon by the fish (in $\%$ of ingested carbon).

As the biomass of epiphytes equals that of leaf tissue on $P$. oceanica leaf tips (averaged measurement on the upper $15 \mathrm{~cm}$, annual basis; HAVELANGE, unpubl.), it was assumed that biomass epiphyles $_{\text {ing }}$ biomass $_{\text {eaves }}=1$. Dried P. oceanica leaves contain 34\% organic carbon (GoBerT et al., 1995); S. alpa assimilates $20 \%$ of the ingested organic matter (VeLImiRov, 1984); dried epiphytes (non-decalcified) contain $7 \%$ of organic carbon (GoberT et al., 1995); $S$. salpa assimilates $40 \%$ of that organic carbon: averaged value estimated from Montogomery \& Gerking (1980), Lobel \& OgdeN (1981). Edwards \& HoRn (1982) and Gerking (1984). Thus, as $S$. salpa only grazes on the leaf tips, $\mathrm{rc}_{\mathrm{enphpy}} / \mathrm{rc}_{\text {leaves }}$ can be estimated from equation (2) to be $0.4($ i.e. $1 \times 7 \times 40 / 34 \times 20)$.

\section{Results}

There were no significant differences between the mean RLG of the different length classes (Table 1, cross $t$-test, $\mathrm{P}>0.05$ in all cases). All values were higher than 3 , ranging from 4.5 to 5.0. Stomach contents comprised a mixture of epilithic algae most often Halopteris and Dictyota - and P. oceanica leaf pieces and epiphytes 
Table 1. S. salpa: length classes, mean relative length of gut $=$ RLG (standard deviation and sample size in parentheses) and qualitative information on the main diet components for each age-class based on in situ observations and direct analysis of stomach contents.

\begin{tabular}{lccl}
\hline age group & $\begin{array}{c}\text { total } \\
\text { length }[\mathrm{cm}]\end{array}$ & RLG & diet \\
\hline $\begin{array}{l}\text { juveniles } \\
\text { young } \\
\text { sub-adults }\end{array}$ & $\begin{array}{l}5-15 \\
15-23\end{array}$ & $\begin{array}{l}4.5(0.7 ; \mathrm{n}=5) \\
5.0(0.7 ; \mathrm{n}=17)\end{array}$ & $\begin{array}{l}\text { plankton (+ few fragments of seaweed) } \\
\text { turf epilithic algae (mainly small Halopteris) } \\
\text { erect epilithic algae (mainly Halopteris and Dictyota), } \\
+ \text { P. oceanica leaf and epiphytes }\end{array}$ \\
adults & $>23$ & $4.7(0.1 ; \mathrm{n}=8)$ & $\begin{array}{c}\text { P.oceanica leaf and epiphytes (+erect Halopteris and } \\
\text { Dictyota) }\end{array}$ \\
\hline
\end{tabular}

(Table 1). Vagile fauna, gastropods (Gibbula spp., Rissoa spp.) and crustaceans (isopods, mysids), were rarely recorded in digestive contents. Pieces of $P$. oceanica leaves were generally well-preserved and were often covered with epiphytes, even in the distal part of the intestine or in the faeces. Some leaves showed small grinding marks by pharyngeal teeth. Note that we rarely observed large specimens of $S$. salpa grazing on epilithic algae.

The average $P$. oceanica leaf $\delta^{13} \mathrm{C}$ was -14.3 (Fig. 2). Mean values for epiphytes $(-17.7)$ and epilithic alge $\delta^{13} \mathrm{C}(-21.7$ to -19.1$)$ were lower than those for seagrass leaves. Considering the relative abundance of Dictyota and Halopteris in the study site -15 and $85 \%$ of substrate cover, respectively (JANSSENS, pers. comm.) - the mean $\delta^{13} \mathrm{C}$ of the epilithic algal community has been calculated to be -21.4 . The fish muscle $\delta^{13} \mathrm{C}$ varies from -20.4 to -16.1 among the different length classes. Mean $\delta^{13} \mathrm{C}$ of the general fish population $(-16.8)$ has been calculated, taking into account all length classes, except the juvenile one, because they are not true benthic

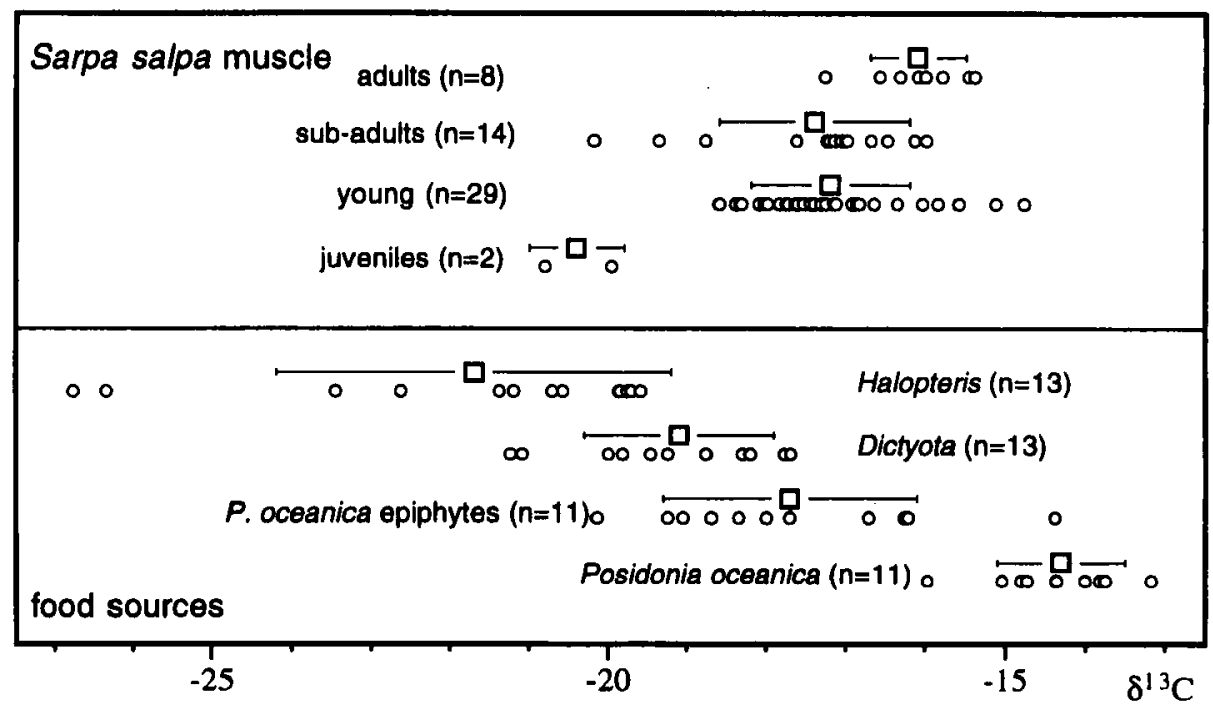

Fig. 2. $\delta^{13} \mathrm{C}$ measurements and mean values in Sarpa salpa muscle and food sources $(\mathrm{n}=$ sample size; error bars $=$ standard deviation). 
Table 2. Literature data on $P$. oceanica carbon stocks and fluxes in the Bay of Calvi ( $10 \mathrm{~m}$ depth).

stocks $\left[\mathrm{g} \mathrm{C} \cdot \mathrm{m}^{-2}\right]$, fluxes $\left[\mathrm{g} \mathrm{C} \cdot \mathrm{m}^{-2} \cdot \mathrm{a}^{-1}\right]$ and ratios

source

stocks

S. salpa biomass

fluxes

$P$. oceanica leaf net primary production

$0.8 \quad$ Houziaux, 1993

$P$. oceanica epiphytes net primary production $\quad 82$

leaf consumption by $S$. salpa

$S$. salpa net production

ratios

fauna vs flora epiphytic biomass

$S$. salpa carbon assimilation efficiency

0.4 LEPOINT et al, in press

0.2 VELIMIROV, 1984

grazers. Combining these values $\left(\delta^{13} \mathrm{C}=-14.3,-17.7,-21.4\right.$ and -16.8 for seagrass, epiphytes, epilithic algae and fishes, respectively) in the equations (1) to (3), the relative contributions of seagrass, epiphytes and algae to $S$. salpa carbon uptake have been calculated to be 40,17 and $43 \%$, respectively.

A box-flux model of carbon transfer through the $S$. salpa compartment can be constructed from our results and previous data on the same site (Table 2). The model obtained (Fig. 3) indicates that $S$. salpa ingests $41.8 \mathrm{~g} \mathrm{C} \cdot \mathrm{m}^{-2} \cdot \mathrm{a}^{-1}$ from

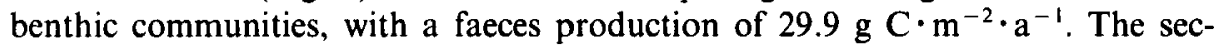

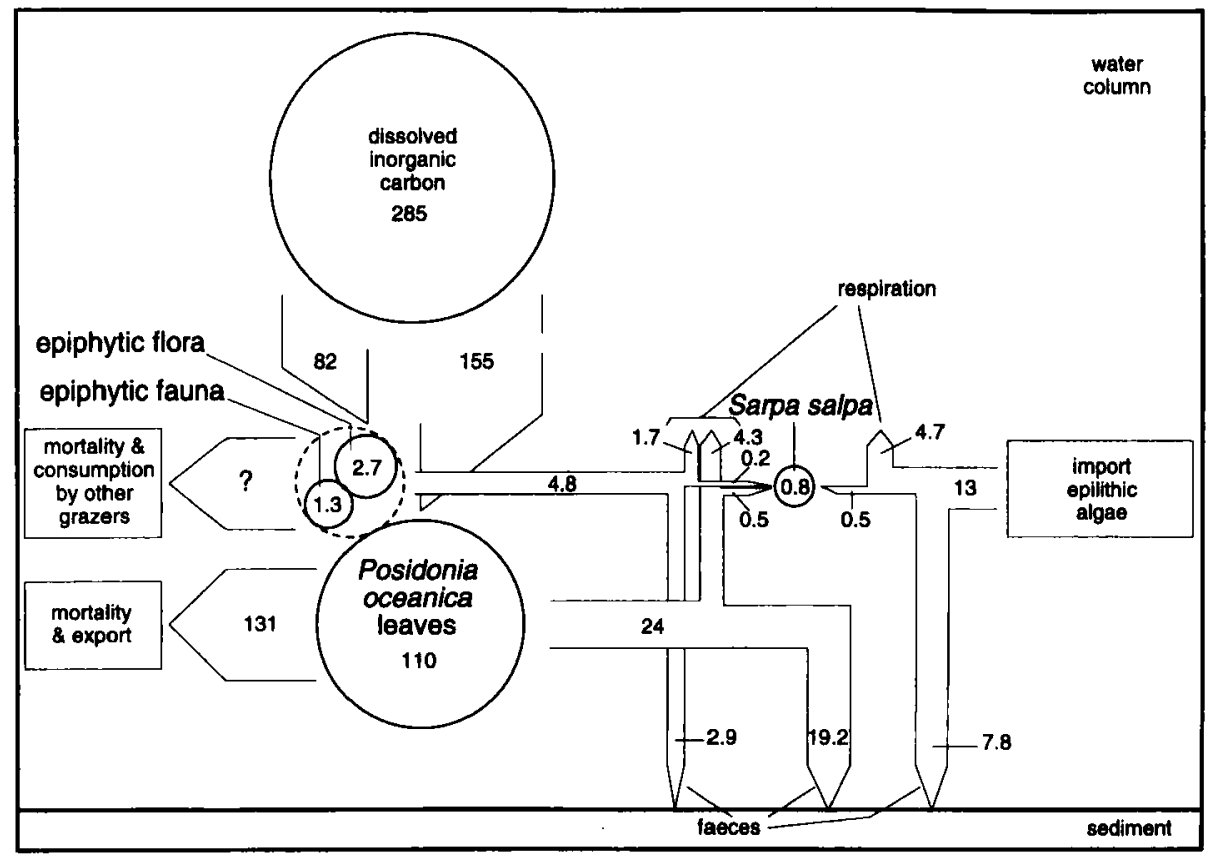

Fig. 3. Box-flux model of carbon transfer towards Sarpa salpa at $10 \mathrm{~m}$ depth in the Bay of Calvi. Arrows are carbon fluxes $\left[\mathrm{g} \mathrm{C} \cdot \mathrm{m}^{-2} \cdot \mathrm{a}^{-1}\right]$, spheres are stocks $\left[\mathrm{g} \mathrm{C} \cdot \mathrm{m}^{-2}\right]$. 
ondary net production of $S$. salpa in Revellata Bay is estimated to be $1.2 \mathrm{~g}$ $\mathrm{C} \cdot \mathrm{m}^{-2} \cdot \mathrm{a}^{-1}$ (sum of three energy fluxes displayed in Fig. 3).

\section{Discussion}

Based on the relative gut length measurements, $S$. salpa is to be considered as a true herbivore. Juvenile $S$. salpa, however, are considered to be plankton feeders (FAGGIANELLI \& COOK, 1981; WhITFIELD, 1985), although some seaweed fragments have been found in the stomach contents. Consumption of epilithic algae varies within the young, sub-adult and adult groups: the young specimens graze on turf algae (mainly small Halopteris spp.), while sub-adults and adults graze on erect algae (large Halopteris spp. for more than $75 \%$, mainly Dictyota for the rest). No data were available on large adults (TL $>35 \mathrm{~cm}$ ), but VerLaque (1990) noted that some large adult specimens had stomachs filled with seagrass leaves and epiphytes. As, in addition, we never observed large specimens grazing on epilithic algae, we consider large adults as generally feeding on $P$. oceanica leaves only.

Our $\delta^{13} \mathrm{C}$ measurements are in good agreement with previous data on both $P$. oceanica collected at the same depth (Bricout et al., 1980; CoOPER \& De Niro, 1989) and algae (FRY et al., 1982; KitTING et al., 1984).

The variability of fish muscle $\delta^{13} \mathrm{C}$ reflects the above-mentioned heterogeneity in diet. A similarity is more evident for adult specimens, whose mean $\delta^{13} \mathrm{C}$ is quite close to that of $P$. oceanica leaves, indicating that the diet of large animals is probably dominated by seagrass.

Sarpa salpa ingests huge amounts of living $P$. oceanica leaf tissue in response to the relatively poor digestibility of seagrass material with high ligno-cellulose fibre content (OTT \& MAURER, 1977). However, it displays a diversified feeding strategymixed diet of seaweed, epiphytes and seagrass leaves - as described for most seagrass grazers in tropical waters (OGDEN, 1976; LoBEL \& OGDEN, 1981; KLUMPP \& Nichols, 1983). A spatio-temporal study of $P$. oceanica leaf-epiphyte communities of Revellata Bay showed that the animal biomass accounts for about $30 \%$ of the total epiphytic biomass at $10 \mathrm{~m}$ depth (LEPOINT et al., in press). So, given that epiphytes contribute up to $17 \%$ of diet, and assuming a similar digestion efficiency between fauna and flora, assimilation of animal matter could reach $5 \%$ of the total assimilated carbon. This animal organic matter probably represents an essential source of animal nitrogen in the $S$. salpa diet, as already shown for tropical fish species (KLumPP \& Nichols, 1983; KlumpP et al., 1989).

The present study reveals the variability of the $S$. salpa diet between the different fish length classes. Small amounts of seaweed found in the stomach of some juvenile specimens could stem from ingestion of small pieces of floating algae as well as from grazing small erect epiphytes of $P$. oceanica (CHRISTENSEN, 1978; HARMELINVIVIEN et al., 1995; B. VelimiRov, pers. comm.); however, this carbon uptake could be minor as muscle $\delta^{13} \mathrm{C}(-20.4$, Fig. 2) and is similar to that of plankton which is about -21 according to DAUBY et al. (1990). $\delta^{13} \mathrm{C}$ measurements, stomach content analysis and in situ observations showed that the grazing of larger individuals on phytobenthos could range from full algal to mixed algal-seagrassepiphytes consumption and finally to only seagrass uptake. This age-dependent diet shift is consistent with an adaptative grazing on the epilithic algae biocenosis 
according to territory range, food availability and grazing capacity (mouth aperture), as suggested by VERLAQUE (1990).

Finally, S. salpa ingests $15 \%$ of primary production of $P$. oceanica leaf and $4 \%$ of epiphytic algae, which is in good accordance with herbivore rates compiled by CYR \& PACE (1993). From secondary net production and mean biomass, one can calculate the turn-over of fish biomass as $1.5 \cdot \mathrm{a}^{-1}$, which is in agreement with conclusions drawn for other fish species of similar size range (SHELDON et al., 1972).

\section{Summary}

The use of stable carbon isotopes determination - in $S$. salpa and in its potential food sources - definitively answers the question whether $S$. salpa does or does not assimilate the large amounts of ingested $P$. oceanica leaf tissue. Sarpa salpa clearly has an age-related mixed diet: juveniles are plankton-feeders, young, sub-adults and adults are herbivorous (algae, $P$. oceanica leaf and its epiphytes) and, the older the individual, the higher the relative contribution of assimilated $P$. oceanica leaf tissue.

Owing to its large-spectrum herbivory, its large biomass, its important faeces production, which is available to meso- and micro-grazer activity and ultimately to remineralization by the microbial compartment, it appears that $S$. salpa, in Revellata Bay where it dominates the macro-grazer community, plays an important role in the regulation and transformation of primary production.

\section{Acknowledgements}

We wish to thank Prof. B. Velimirov and Prof. A. Distèche for their helpful advice, S. Gobert and D. Graux for their help during collecting data and samples, R. Biondo and L. BERnARd for technical assistance. Prof. F. Mosora is acknowledged for the facilities she offered in isotope ratio mass spectrometry analyses. Field work was carried out at the STARESO research station, thanks to $\mathrm{Mr} \mathbf{G}$. BONIFAC IO, Dr D. BAY, Dr P. LEJEUnE and their staff. This study was supported by grants of the EU (STEP-CT90-0063-c(CD)), of the Belgian National Fund for Scientific Research (FRFC 2.4563.93) and of the Foundation for Submarine and Oceanographic Research of the University of Liège (Belgium).

\section{References}

BAY, D., 1984: A field study of the growth dynamics and productivity of Posidonia oceanica (L.) DeLILE in the Calvi bay, Corsica. Aquat. Bot., 20: 43-64.

Bouquegneau, J. M., P. Dauby, M. Soullard, S. Gobert, J. P. Nellissen \& S. Havelange, 1994: Elements stocks and fluxes in the Posidonia oceanica ecosystem of the Mediterranean. In: $\mathbf{M}$. JANGioux (Ed.), STEP research programme. Final report. Contrat Step-0063-C, Brussels: 47-56.

Bricout, J., C. F. Boudouresque, G. Giraud \& P. Panayotidis, 1980: Le rapport ${ }^{13} \mathrm{C} /{ }^{12} \mathrm{C}$ chez Posidonia oceanica et Cymodocea nodosa. Trav. Sci. Parc Natl Port-Cros, 6: 289-292.

Crbrian, J., C. M. Duarte, N. Marba, S. Enriquez \& B. Olesen, 1996: Herbivory on Posidonia oceanica: magnitude and variability in the Spanish Mediterranean. Mar. Ecol. Prog. Ser., 130: 147-155.

Christensen, M. S., 1978: Trophic relationships in juveniles of three species of sparid fishes in the South African marine littoral. Fish. Bull., 76: $389-401$. 
CoOper, L. W. \& M. J. De Niro, 1989: Stable carbon isotope variability in the seagrass Posidonia oceanica: evidence for light intensity effects. Mar. Ecol. Prog. Ser., 50: 225-229.

CYr, H. \& M. L. PACE, 1993: Magnitude and patterns of herbivore in aquatic and terrestrial ecosystems. Nature, 361: 148-150.

Dauby, P., 1989: The stable carbon isotope ratios in benthic food webs of the Gulf of Calvi, Corsica. Cont. Shelf Res., 9: 181-195.

-, F. Mosora \& M. Vertez, 1990: A yearly study of ${ }^{13} \mathrm{C} /{ }^{12} \mathrm{C}$ isotopic ratio variations in the Calvi's Bay plankton. Rapp. Comm. Int. Mer Médit., 32: 201-202.

- \& M. Poulicek, 1995: Methods for removing epiphytes from seagrasses: SEM observations on treated leaves. Aquat. Bot., 52: 217-228.

DE NiRo, M. J. \& S. EPSTEIN, 1978: Influence of diet on the distribution of carbon isotopes in animals. Geochim. Cosmochim. Acta, 42, 495-506.

EDWARDs, T. W. \& M. H. HorN, 1982: Assimilation efficiency of a temperate-zone intertidal fish (Cebidichthys violaceus) fed diets of macroalgae. Mar. Biol., 67: 247-253.

Faggianelll., D. J. \& E. Cook, 1981: Contribution à l'étude de l'écologie de la saupe (Sarpa salpa L.) sur la côte occidentale de la Corse. Rapport Ingiéniorat, Univ. Sci. et Tech. du Languedoc, France; 92 pp.

Frankignoulle, M. \& J. M. Bouquegneau, 1987: Seasonal variation of the diel carbon budget of a marine macrophyte ecosystem. Mar. Ecol. Prog. Ser., 38: 197-199.

Fry, B., R. Lutes, M. Northam, P. L. Parker \& J. Ogden, 1982: A ${ }^{13} \mathrm{C} /{ }^{12} \mathrm{C}$ comparison of food webs in Caribbean seagrass meadows and coral reefs. Aquat. Bot., 14: 389-398.

-- S. A. Macko \& J. C. Zieman, 1987: Review of stable isotopic investigation of fo8d webs in seagrass meadows. Fla Mar. Res. Publ., 42: 189-209.

Gerking, S. D., 1984: Assimilation and maintenance ratios of an herbivorous fish, Sarpa salpa, feeding on a green alga. Trans. Am. Fish. Soc., 113: 378-387.

Giraud, G., 1979: Sur une méthode de mesure et de comptage des structures foliaires de Posidonia oceanica (LINNÉ) DeLILE. Bull. Mus. Hist. Nat. Marseille, 39: 33-39.

Gobert, S., S. Belkhiria, P. Dauby, S. Havelange, M. Soullard, J. M. Bouquegneau, 1995: Variations temporelles des stocks de carbone et d'azote de la frondaison de l'herbier de posidonies de la Baie de la Revellata (Calvi, Corse). Bull. Soc. R. Sci. Liège, 64(4-5): 263-284.

Harmelin-Vivien, M. L., J. G. Harmelin \& V. Leboulleux, 1995: Microhabitat requirements for settlement of juvenile sparid fishes on Mediterranean rocky shores. Hydrobiologia, 300/301: 309 320.

Houziaux, J. S., 1993: Approche quantitative des relations entre Sarpa salpa (LinNÉ, 1758) (Téléostéen, Sparidae) et I'herbier de posidonies dans la Baie de la Revellata (Calvi, Corse). Mém. Lic. Sc. Zool. Université de Liège, Belgique; $53 \mathrm{pp}$.

Kerneis, A., 1960: Contribution à l'étude faunistique et écologique des herbiers de posidonies de la région de Banyuls. Vie Milieu, 11: 145-187.

Kitring, C. L., B. Fry \& M. D. MORGaN, 1984: Detection of inconspicuous epiphylic algae supporting food webs in seagrass meadows. Oecologia, 62: 145-149.

Klumpr, D. W., R. K. Howard \& D. A. Pollard, 1989: Trophodynamics and nutritional ecology of seagrass communities. In: A. W. D. Larkum, A. J. Mccomb \& S. A. Shepherd (Eds.), Biology of seagrasses. Elsevier, Amsterdam: 394-457.

- \& P. D. Nichols, 1983: Nutrition of the southern sea garfish Hyporhamphus melanochir gut passage rate and daily consumption of two food types and assimilation of seagrasses components. Mar. Ecol. Prog. Ser., 12: 207-216.

Lipoint, G., S. Havelange \& J. M. Bouquegneau, in press: Variation on the biomass of the leaf epiphytes in a Posidonia oceanica seagrass bed (Revellata Bay, Corsica). Cah. Biol. Mar.

LIBES, M., 1985: Contribution à l'étude de la production primaire des herbiers à Posidonia oceanica par la méthode du carbone 14 appliquée in situ. J. Rech. Océanogr., 10: 2428.

Lobfl, P. S. \& J. C. OGden, 1981: Foraging by the herbivorous Parrotfish Sparissoma radians. Mar. Biol., 64: 173-183.

LORENTI, M. \& E. Fresi, 1983: Grazing of Idotea bamca on Posidonia oceanica: preliminary observations. Rapp. Comm. Int. Mer Médit., 28: 147-148.

Mazzella, L., M. C. Buia, M. C. Gambi, M. Lorenti, G. F. Russo, M. B. Scipione \& V. Zupo, 1992: Plant-animal interactions in the marine benthos. In: D. M. John, S. J. Hawkins \& J. H. PRICE (Eds.), Systematics Association, special volume No. 46. Clarendon Press, Oxford: 165-187.

Meinesz, A., C. F. Boudouresque \& J. R. Lefevre, 1988: A Map of the Posidonia oceanica Beds of Marina d'Elbu (Corsica, Mediterranean). P.S.Z.N.I: Marine Ecology, 39: 243-252.

Montgomery, W. L. \& S. D. Gerking, 1980: Marine macroalgae as food for fishes: an evaluation of potential food quality. Environ. Biol. Fish., 5: 143-153.

Nedelec, H. \& M. Verlaque, 1984: Alimentation de l'oursin Paracentrotus lividus (Lamarck) dans un herbier à Posidonia oceanica (L.) Delile en Corse (Méditerranée - France). In: C. F. BoubouResque, A. Jeudy De Grissac \& J. Olivier (Eds.), International Workshop on Posidonia oceanica beds. GIS Posidonie, Marseille: 349-364. 
OGden, J. C., 1976: Some aspects of herbivore-plant relationships on Carribbean reefs and seagrass beds. Aquat. Bot., 2, 103-116.

OTt, J. A. \& L. Maurer, 1977: Strategies of energy transfer from marine macrophytes to consumer level: the Posidonia oceanica example. In: B. F. KeEgan, P. O'Ceidigh \& P. Boaden (Eds.), Biology of benthic organisms. Pergamon Press, Oxford: 493-502.

Pergent, G., 1993: L'herbier à Posidonia oceanica (L.) Delile. Approche structurale, fonctionelle et appliquée. Diplome d'habilitation à diriger des recherches, Université de Corse, France; $127 \mathrm{pp}$.

--, J. Romero, C. Pergent-Martini, M. A. Mateo \& C. F. Boudouresque, 1994: Primary production, stocks and fluxes in the Mediterranean seagrass Posidonia oceanica. Mar. Ecol. Prog. Ser., 106: 139-146.

Romero, J., M. Perez, M. A. Mateo \& E. SAla, 1994: The below ground organs of the Mediterranean seagrass Posidonia oceanica as a biogeochemical sink. Aquat. Bot., 47: 13-19.

Sheldon, R. W., A. Prakash \& W. H. Sutcliffe, Jr., 1972: The size distribution of particles in the ocean. Limnol. Oceanogr., 17: 327-340.

SOFER, Z, 1980: Preparation of carbon dioxide for stable carbon isotope analysis of petroleum fractions. Anal. Chem., 52: 1389-1391.

Soullard, M., I. Bourge, J. Fogel, D. Lardinois, T. Mathieu, C. Veeschkens, D. Bay, P. Dauby \& J. M. Bouquegneau, 1994: Evolution of the shoot density of the Posidonia seagrass bed of Calvi Bay (Corsica). Vie Milieu, 44: 199-201.

SUYEHIRO, Y., 1942: A study of the digestive system and feeding habits of fish. Jpn. J. Zool., 10: 1-300.

Traer, K., 1980: The consumption of Posidonia oceanica (L.) Delile by echinoids at the Isle of Ischia. In: M. JANGoux (Ed.), Echinoderms: present and past. A. A. Balkema, Rotterdam: 241-244.

Velimirov, B., 1984: Grazing of Sarpa salpa L. on Posidonia oceanica and utilization of soluble compounds. In: C. F. Boudouresque, A. Jeudy de Grissac \& J. Olivier (Eds.) International Workshop on Posidonia oceanica beds. GIS Posidonie, Marseille: 381-387.

-- \& M. WALENTA-Simon, 1992: Seasonal changes in specific growth rates, production and biomass of a bacterial community in the water column above a Mediterranean seagrass system. Mar. Ecol. Prog. Ser., 80: 237-248.

- - \& WALENTA-SimON, 1993: Bacterial growth rates and productivity within a seagrass system: seasonal variations in a Posidonia oceanica bed. Mar. Ecol. Prog. Ser., 96: 101-107.

Verlaque, M., 1990: Relation entre Sarpa salpa (Linneaus, 1758) (Téléostéen, Sparidae), les autres poissons brouteurs et le phytobenthos algal méditerranéen. Oceanol. Acta, 13: 373-388.

Whitehead, P. J. P., M.-L. Bauchot, J.-C. Hureau, J. Nielsen \& E. Tortonese, 1986: Fishes of the North-eastern Atlantic and the Mediterranean, Volume II. UNESCO, Paris; $1007 \mathrm{pp}$.

Whitel.D, A. K., 1985: The role of zooplankton in the feeding ecology of fish from some southern African estuaries. S. Afr. J. Zool., 20: 166-171.

Zupo, V. \& E. Fresi, 1984: A study on the food web of the Posidonia oceanica (L.) Delile ecosystem: analysis of the gut contents of Echinoderms. In: C. F. Boudouresoue, A. JeUdy DE GriSSAC \& J. OLIVIER (Eds.), International Workshop on Posidonia oceanica Beds. GIS Posidonie, Marseille: $373-379$. 